\section{Contents}

\section{TH ANNIVERSARY OF EPS}

Europe in 1965-1968

by F. Bevilacqua, E. Giannetto, G. Tagliaferri

The European Physical Society and Scientific

Freedom

by A.R. Mackintosh

Ensuring East European Participation

by $F$. Janouch

Anticipating EPS on a Reduced Scale by G.-J. Béné

The Divisions of EPS: The Early Years

\section{Constituting the Divisions}

by P.G. Boswell

The Hewlett-Packard Europhysics Prize by M. Peter

The High Energy and Particle Physics Prize by R. Gastmans

EPS and the International Science by M. Jacob

The Publications of EPS

by E.N. Shaw

AUSTRON

Student Mobility Scheme Underway

From Athens to Paris

Advances in Solar Physics

\section{EPS DIRECTORY}

Executive Committee, Delegates to Council Action Committees

Member Organizations, Collaborating Societies Associate Members

Divisions, Interdivisional Groups

European Physical Society

\title{
A Good Job Well Done
}

Rejoice and be glad. How rarely are we these days encouraged by the news media to feel satisfaction when it is not a competitive situation and "we" have defeated "them". If "we" have cooperated with "them" to produce something good, then we are asked to bewail the fact that it was not sooner or cheaper or different somehow. We are assailed by scandals, piqued by malpractices, oppressed by missed opportunities; almost never encouraged to be simply pleased.

Yet on this 25th anniversary of the European Physical Society, let this be our primary reflection. A difficult task accomplished; idealism and enthusiasm overcoming our inherent sense of mistrust and the universal tendency to isolationism. Well done all around.

As we dip into the background of our Society, we should remember that we are reading only a sample of the multitude of actions that over the years have built the Society. Far more people made selfless and essential contributions than are mentioned in the following pages.

It is a popular saying that nobody learns from history and all histories are merely a record of the authors' prejudices. Certainly we cannot oblige those who come after to learn from their predecessors, but we have, nevertheless, a duty to leave some sort of record so that they can do so, if they have the mind.

In the early stages of considering a commemorative document, a more ambitious and complete account of the formation and the development of the EPS was mooted. But as so often in the past, the action had to be tailored to the means, and these despite the contributions of advertisers, would not run to the costly research, cross-checking and then the drafting of a formal history. The idea of an anniversary booklet mutated into this special sponsored issue of Europhysics News, which also

\section{European Physical Society}

Europhysics News is the journal of the European Physical Society that acts through Divisions, Sections and Groups to promote collaboration among physicists. Subscription price: SFR 135-- per annum.

\section{Editorial Board}

P. Bochsler, Bern University

A.-J. Dianoux, ILL, Grenoble

F. James, CERN, Geneva

T. Jarlborg, Geneva University

M. Siegrist, EPFL, Lausanne

Editorial and Advertising

\section{Editorial and Advertising}

EPS Secretariat, P. O.Box 69

$\mathrm{CH}-1213$ Petit-Lancy 2, Geneva

Telephone: $\quad+41(22) 7931130$

Telefax: $\quad+41(22) 7931317$ E-mail: epnews@cernvm.cern.ch Advertising is charged according to space, on a sliding scale ranging from SFR 2700.- for a full page to SFR 700.- for a one-sixth page. Rates for four-colour and cover advertising, and series insertions, on application. Special rates for Associate Members of EPS; $25 \%$ reduction for announcements of situations vacant.
President: N. Kroo, KFKI

Budapest

Exec. Sec.: M. Thomas

Editor: P.G. Boswell first week of month of publication.

Subscriptions \& EPS Fees:

Société de Banque Suisse,

Geneva; Acc. No. 164.899

Swiss Post Office Acc.: CCP

Geneva 12-19107-4

German Post Office Acc.: Postbank

Karlsruhe 1801-30-754

Eurocheque to EPS, Geneva

EPS Budapest Secretariat

Nádor u. 7, H-1051 Budapest

Telephone: +36 (1) 1173510

Telefax: $\quad$ +36 (1) 1176817
Deadline for advertising orders:

\section{Cover illustrations}

On the left, an artist's sketch of the proposed international AUSTRON neutron spallation source for which a detailed technical design is planned (see page 156).

On the right, the public face of the European Physical Society over the years. From the top:

- The 1972 meeting of the Council of EPS in Wiesbaden.

- The EPS Advisory Committee on Publications at the German Physical Society's Bad Honnef conference centre in 1988.

- The opening session of the second General Conference (Wiesbaden, October 1972).

- Gerd Binnig, with Heinrich Rohrer in the background, winners of the 1984 Hewlett-Packard Europhysics Prize. Binnig is shown here holding the prize certificate shortly after it was awarded at the EPS-6 General Conference Trends in Physics in Prague.

- The Plenary Session on 8 April 1969 of the Inaugural Conference of the EPS in the Salone dei 500, Palazzo Vecchio, Florence.

- Gilberto Bernardini (on the right) being interviewed for Italian television during the Inaugural Conference of EPS in Florence.

combines the annual Directory together with some subsidiary information to give a snapshot view of our Society today. The number of topics had necessarily to be restricted, the major omission perhaps being the development of activities by the Action Committees.

Another factor was the reluctance of those who had played some of the more important rôles to commit themselves to paper. The innate caution of physicists in general proved to be a barrier. The rigours of scholarship are not compatible with a breezy rifling through the memories of the years. A reluctance to commit may not be entirely due to scientific caution. In the laboratory (at least in Europe) the fear of being wrong - and being found out - can often explain much. Here it is something else. Memories are fragile things and with the passage of time can become arbitrarily uncertain. That alone is inhibiting because few people have personal records of their voluntary acts that are as ordered as their professional. Moreover, so much of what was done for the EPS was done by teams of people with no structured hierarchy, all of whom would be operating primarily in their own territories. In such circumstances it is very difficult for one person to present an overall picture.

So let us treat this issue as a taste of the EPS through the years and as we reflect on its evolution, instead of just not regretting that it had not become bigger, or more wealthy, let us above all express our thanks to the hundreds of physicists whose contributions made the EPS possible. 